\title{
G070053
}

\section{パイオディーゼル/ブタノール/軽油のディーゼル燃焼特性 （ハイイディゼルになたね油とパーム油のメチルエステルを用いた場合）}

尾堂 裕之*1, 木下 英二*2 , 吉本 康文 ${ }^{* 3}$

\section{Diesel Combustion Characteristics of Biodiesel/Butanol/Gas Oil Blends (Study with Rapeseed Oil and Palm Oil Methyl Esters Used as Biodiesel)}

\author{
Hiroyuki ODO $^{* 1}$, Eiji KINOSHITA*2 and Yasufumi YOSHIMOTO*3 \\ ${ }^{* 1}$ Kagoshima University, Department of Mechanical Engineering \\ Korimoto 1-20-40, Kagoshima-shi, Kagoshima, 890-0065 Japan
}

In order to improve the lubricant property of 1-butanol/gas oil blend, adding rapeseed oil methyl ester (RME) and palm oil methyl ester (PME) to 1-butanol/gas oil blend was tried, and the fuel properties, combustion characteristics and exhaust emissions of the blend fuels with 40 mass\% 1-butanol were investigated using a DI diesel engine. By adding RME and PME to 1-butanol/gas oil blend, the kinematic viscosity increases, the ignition delay becomes shorter, and the smoke emission reduces due to the increase in the oxygen content of the fuel.

Key Words: Diesel Engine, Alternative Energy, Liquid Fuel, Biomass Energy, Biodiesel, 1-Butanol, Exhaust Emission

\section{1. 緒 論}

バイオブタノールは, バイオエタノール同様, 種々の有機物から発酵により製造可能であり(1), ブタノールは エタノールより低酸素含有率であるが，セタン価が幾分高く，水の吸湿性が低く，軽油との相溶性があるため, ディーゼル機関への適用が容易であると考えられる．ブタノールはJIS 2 号軽油より動粘度が低いため, 高濃度 ブタノール混合軽油による長期間使用は燃料噴射系の摺動面を摩耗させ, エンジントラブルを引起す恐れがある. これを解決する方法の 1 つとして, JIS 2 号軽油より約 2 倍高動粘度のバイオディーゼル（以後, BDF と記述）を 添加した 3 種混合然料が考えられる. 3 種混合燃料の性状に関する研究はバーム油BDF を用いた研究 ${ }^{(2)}$ があるが， 日本のような地域での低温流動性について考慮されていない. 著者らは，1-ブタノール混合軽油になたね油メチ ルエステル（RME），またはパーム油メチルエステル（PME）を添加した場合について，相溶性，相状態（液体, 曇り液体，ゲル，固体等，相分離を含む）に及ぼす温度の影響，動粘度，流動点，および使用可能と予想される 混合割合について報告した(3)

本研究では，1-ブタノール混合軽油に RME，またはPME を添加した燃料を直噴式ディーゼル機関に適用して 実験を行ない，燃焼・排ガス特性について検討した。今回は，高濃度 1-ブタノール混合軽油として，1-ブタノー ル混合割合が 40mass\%のものを対象とし，軽油部分を一部または全部，RME，またはPMEに置き換えた混合燃 料を用いた。ささに，1-ブタノール 40mass \% 混合軽油の酸䒺含有率 $8.6 \mathrm{mass} \%$ とほぼ同じとなる RME $80 \mathrm{mass} \%$ 混合軽油, PME75\%混合軽油の実験も行い, 排ガス中の Smoke 濃度に及ぼす1ーブタノールと RME, PMEの違い についても検討した.

\section{2. 供試燃料}

供試然料として，JIS 2 号軽油（Gas Oil），1-ブタノールの混合割合を 40mass\%一定 ${ }^{(4)}$ として，軽油の混合割合 を0〜60mass\%まで $20 \mathrm{mass} \%$ 毎変化させ，残りをなたね油メチルエステル（RME），パーム油メチルエステル

\footnotetext{
"1 学生員, 鹿児島大学大学院 理工学研究科（T890-0065 鹿児島市郡元 1-20-40）

*2 正員, 鹿児島大学大学院 理工学研究科

*3 正員, 新潟工科大学

E-mail: kinoshit@mech.kagoshima-u.ac.jp
}

[No.12-1] 日本機械学会 2012 年度年次大会講演論文集 [2012.9.9-12, 金沢] 
(PME) とする混合燃料（B40G60, B40G40R20, B40G20R40, B40R60, B40G40P20, B40G20P40, B40P60, こ こで B は1-ブタノール，G は Gas Oil，R はRME，PはPME を表し，数值は質量割合を表す）を用いた．表 1 に ベ一ス燃料の性状を示し，表 2 に供試燃料の性状を示す．RME，PME はJIS 規格程度の高品質 BDF である。 ま た１ーブタノール 40mass\% 混合軽油（B40G60）の酸素含有率 8.6 mass \%とほぼ同じとなる RME 80 mass \%混合 軽油（G20R80）, PME 75 mass\%混合軽油（G25P75）も検討対象とした.

表 1，2 の低発熱量, 密度, 動粘度, 流動点, 蒸留温度（T10，T50，T90）は測定值である.1-ブタノールの 流動点には括弧をつけているが，これは凝固点を表す。表 2 から，RME 混合燃料，PME 混合燃料はそれぞれ， RME, PME の混合割合が増加するほど, 密度, 動粘度, 流動点は増加し, 低発熱量は低下することが分かる.

\section{3. 実験装鯂と実験方法}

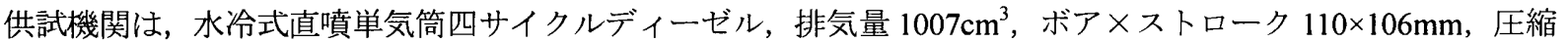
比 16.3 , 連続定格出力は $11.77 \mathrm{kw} / 2200 \mathrm{rpm}$ である. 噴射系は軽油使用時の標準噴射系のままで, 機関回転数を 2000 $\mathrm{rpm}$ 一定として負荷（負荷 $100 \%$ で正味平均有効圧 $\mathrm{BMEP}=0.67 \mathrm{MPa}$ ）を変化させて実験を行った. 排ガス中の $\mathrm{HC}$ 濃度は FID，CO 濃度は NDIR，NOx 濃度は CLD および Smoke 濃度は光透過式スモークメータ（Opacity）を使用 して測定し，シリンダ内圧力および噴射ノズルのニードルリフト（これらは 50 サイクルの平均值）を測定した.

Table 1 Properties of base fuels

\begin{tabular}{|c|c|c|c|c|c|}
\hline \multicolumn{2}{|l|}{ Properties } & \multirow{2}{*}{$\begin{array}{c}\text { RME } \\
54\end{array}$} & \multirow{2}{*}{$\begin{array}{c}\text { PME } \\
64 \\
\end{array}$} & \multirow{2}{*}{$\frac{1 \text {-Butanol }}{18}$} & \multirow{2}{*}{$\begin{array}{c}\begin{array}{c}\text { Gas Oil } \\
(\text { JIS No.2) }\end{array} \\
56 \\
\end{array}$} \\
\hline Cetane number & & & & & \\
\hline Net calorific value & $\mathrm{MJ} / \mathrm{kg}$ & 36.67 & 36.85 & 33.00 & 43.12 \\
\hline Density@288K k & $\mathrm{kg} / \mathrm{m}^{3}$ & 883 & 875 & 795 & 830 \\
\hline $\begin{array}{l}\text { Kinematic viscosity } \\
@ 303 \mathrm{~K}\end{array}$ & $\mathrm{~mm}^{2} / \mathrm{s}$ & 5.35 & 5.37 & $<2$ & 3.04 \\
\hline Pour point & ${ }^{\circ} \mathrm{C}$ & -7.50 & 12.5 & $(-89.5)$ & -17.5 \\
\hline $\mathrm{C}$ & mass \% & 77.1 & 76.3 & 64.9 & 87.3 \\
\hline $\mathrm{H}$ & mass \% & 12.00 & 12.3 & 13.5 & 12.5 \\
\hline $\mathrm{O}$ & mass \% & 10.9 & 11.4 & 21.6 & - \\
\hline $\mathrm{T} 10$ & ${ }^{\circ} \mathrm{C}$ & 336 & 320 & - & 192 \\
\hline T50 & ${ }^{\circ} \mathrm{C}$ & 340 & 328 & - & 274 \\
\hline T90 & ${ }^{\circ} \mathrm{C}$ & 347 & 333 & - & 333 \\
\hline
\end{tabular}

Table 2 Properties of test blended fuels

\begin{tabular}{l|c|c|c|c|c}
\hline Fuels & $\begin{array}{c}\text { Density } \\
@ 288 \mathrm{~K} \\
\mathrm{~kg} / \mathrm{m}^{3}\end{array}$ & $\begin{array}{c}\text { Net } \\
\text { calorific } \\
\text { value } \\
\mathrm{MJ} / \mathrm{kg}\end{array}$ & $\begin{array}{c}\text { K inematic } \\
\text { viscosity } \\
@ 303 \mathrm{~K} \\
\mathrm{~mm}^{2} / \mathrm{s}\end{array}$ & $\begin{array}{c}{ }^{\circ} \mathrm{C} \\
\text { Pour point }\end{array}$ & $\begin{array}{c}\text { Oxygen } \\
\text { mass\% }\end{array}$ \\
\hline B40G60 & 820 & 38.8 & 2.5 & -25.0 & 8.6 \\
\hline B40G40R20 & 832 & 37.8 & 2.7 & -20.0 & 10.8 \\
\hline B40G20R40 & 843 & 36.5 & 2.9 & -17.5 & 13.0 \\
\hline B40R60 & 855 & 35.2 & 3.5 & -17.5 & 15.2 \\
\hline B20R80 & 866 & 38.0 & 4.7 & -10.0 & 8.7 \\
\hline B40G40P20 & 830 & 37.8 & 3.0 & -7.5 & 10.9 \\
\hline B40P60 & 848 & 32.3 & 3.4 & 7.5 & 15.5 \\
\hline G25P75 & 863 & 38.4 & 4.7 & 10.0 & 8.6 \\
\hline
\end{tabular}

\section{4. 実験結果と考察}

表 1 の供試燃料は機関を確実に始動することができ, 無負荷を含む全ての負荷において $2000 \mathrm{rpm}$ 一定で安定し て運転することができた。また，正味熱効率は全ての供試燃料でほぼ同じであった。

図 1 に $\mathrm{BMEP}=0.67 \mathrm{MPa}$ （負荷 $100 \%$ ）での燃料噴射時期，着火時期および着火遅れを示す。これらの值はニー ドルリフトおよびシリンダ内圧力上昇率から求めたものである. 図 1 より，B40 系燃料間では， RME，PME 混合 割合が増加するほど着火遅れは短くなっている．また，RMEに比べPMEの方が高セタン価のため，PME 混合燃 料は RME 混合然料に比べ着火遅れは短くなっている. 図 2 に着火遅れとセタン価の推定值との関係を示寸. 混 合燃料のセタン価は表 1 のベース燃料のセタン価と混合質量割合から見積もった值であり，図中の実線は定性的 傾向を表すために引いたものである. 図 2 より, RME-B40 系燃料以外，セタン価が高くなるほど着火遅れは短く なっていることが分かる. RME-B40 系燃料では，RMEのセタン価は軽油より若干低いにも関わらず，RMEの混 合により着火性が改善している. B40G60 と B40R60 のみに注目しても，同量の 1-ブタノール混合が着火性に及 ぼす影響は軽油と RME とでは異なっている，RME は高沸点成分で構成されており，動粘度も高いので，RME の然料噴霧の微粒化・蒸発は軽油に比べて悪い，また，1-ブタノールは，低沸点・低動粘度であるので物理的着 火遅れは短いが，短鎖の炭化水素であるために化学的着火遅れが長く，化学的着火遅れの方が支配的であるので セタン価が低い.したがって，B40 系燃料において，1-ブタノールの混合により物理的着火遅れは改善するが化 学的着火遅れは長くなると思われる. 今回の実験結果から推測すると, 軽油と RMEの物理的着火遅れの改善に 及ぼす1-ブタノールの効果は, 物理的着火遅れが長いと思われる RME の方が軽油より大きかったと考えられる. このことが B40 系燃料における RME 混合による着火性の改善の原因と考えられる. PME-B40 系燃料においても 同様のことが考えられるが，蒸留温度が RME より低いので，物理的着火遅れの改善に及ぼす 1-ブタノールの効 


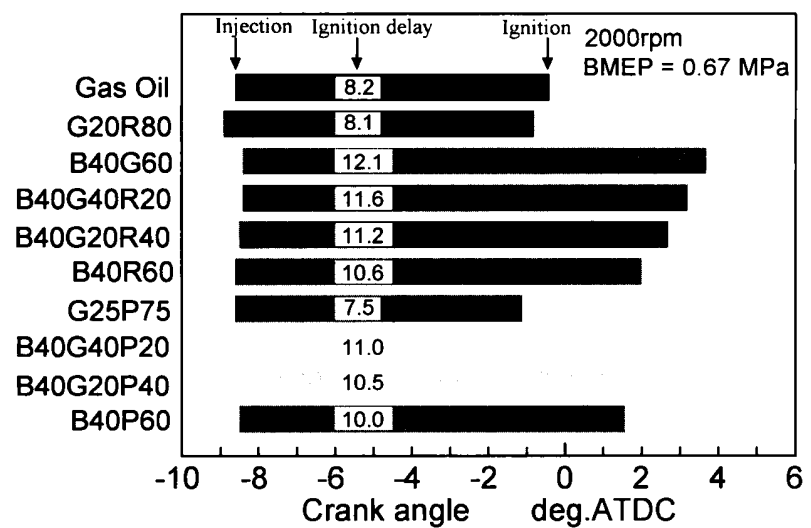

Fig. 1 Injection timing and ignition delay

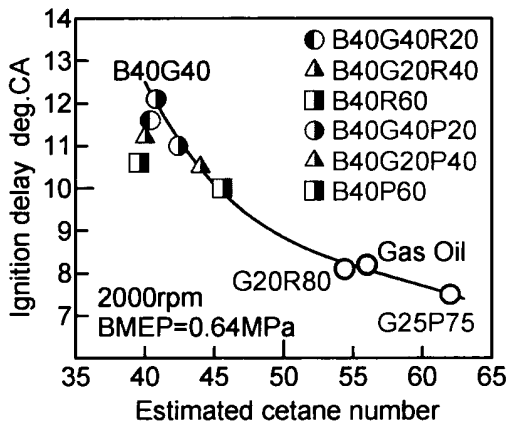

Fig.2 Estimated cetane number vs. ignition delay

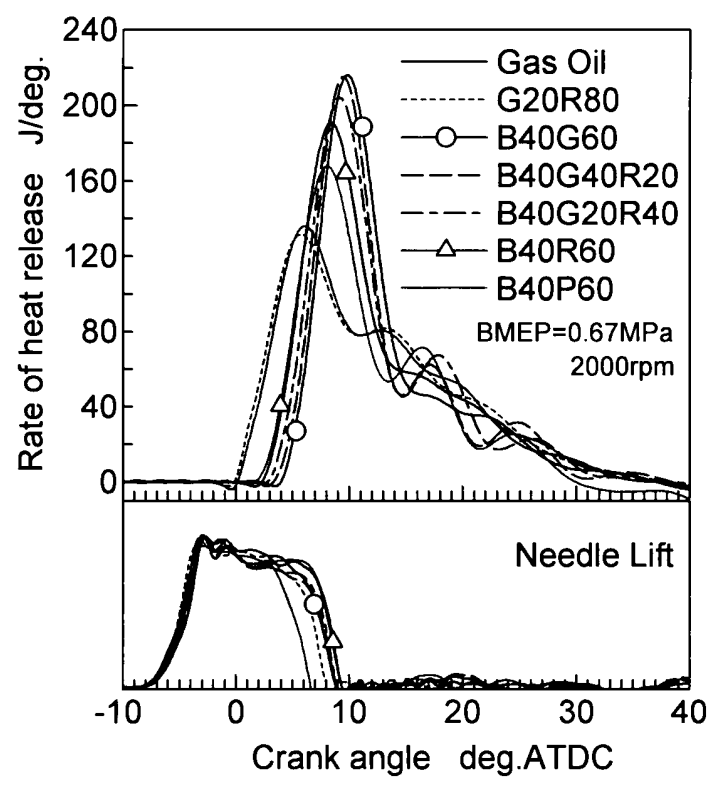

Fig.3 Rate of heat release and needle lift

果はRME 混合に比べて低いと考えられ，そのために，軽油と同様のライン（図 20 の実線）にデータが現れたと 思われる. しかし，これらのことは不明な点も多いので，今後さらに検討寸る必要がある.

図 3 に RME 混合然料の $\mathrm{BMEP}=0.67 \mathrm{MPa}$ に打ける熱発生率線図と噴射ノズルのニードルリフトを示寸.ニード ルリフトから，燃料噴射期間は G20R80の方が軽油より長く，B40 系燃料はさらに長くなっており，また，B40 系燃料間ではRME の混合割合が多いほど長くなっている。これは低発熱量が低い燃料ほど同じ熱量を得るのに より多くの燃料を必要とするためである. 図 1 と図 3 より, 着火遅れが長いほど, 最大熱発生率が高くなってい ることが分かる。 これは，着火遅れが長いほど，着火遅れ期間に形成される叮燃予混合気量が増加し，予混合燃 焼が増大したためと考えられる.燃焼終了は全ての供試然料でほぼ同じであった。

図 4 にRME 混合燃料，図 5 にPME 混合燃料の排ガス中の HC, CO, Smoke および NOx 濃度をBMEP に対し て示す. 図 4 より，RME-B40 系燃料の HC, CO 濃度は, 軽油や G20R80 よりも高く, 特に低負荷に打いて顕著 だが, これは, 着火遅れが長くなり, 空気と過剩に混合して燃料希薄部分を多く形成すると考えられ, この部分 が不完全燃焼を起こすため, 増加したものと考えられる.一方, 高負何では $\mathrm{HC}, \mathrm{CO}$ 濃度共に B40 系燃料は軽油 の值に近づく．これは高負荷の場合，低負荷に比べて燃焼室内ガス温度が高く，HC，CO の生成・排出に対する 影響が少なかったためと考えられる. RME-B40 系燃料間では HC, CO 濃度に及ぼす RME 混合割合の影響は殆ど なかった，一方，図 4 より PME-B40 系燃料間では PME 混合割合の増加に伴い HC, CO 濃度は低くなっている. NOx 濃度は RME 系混合燃料, PME 系混合燃料共に, 低負荷において, B40 系燃料は軽油に比べて低くなってい るが, 高負荷においては PME 混合の影響はほとんどないが, RME 混合の場合, RME の混合割合が増加するほど 若干増加する結果となった. 図 4, 図 5 より Smoke 濃度は高負荷ほど供試然料間で違いが現れる. 図 5 の BMEP $=0.34 \sim 0.67 \mathrm{MPa}$ において, G20R80や G25P75 の Smoke 濃度は軽油より低く, B40 系燃料ではさらに低隇して いる. これらの燃料は酸素を含有しており, ディーゼル噴霧の燃料過濃部分で酸素不足が抑制され，ススの生成 が少なかったためと考えられる. B40 系燃料間を比較すると, RME や PME の混合割合が増加するほど Smoke 濃 度は幾分低下寸る.これは酸素含有率の増加によるものと考えられる.ほほぼ同じ酸素含有率の1-ブタノール混合 軽油（B40G60）, RME 混合軽油（G20R80）, PME 混合軽油（G25P75）を比較すると, 明らかに B40G60の Smoke 濃度の方が G20R80，G25P75 より低い。これは，図 4 に示すようにB40G60 の予混合燃焼割合が G20R80 より多 
いことが原因の $1 つ （ G 25 \mathrm{P} 75$ も同様）と考えられる. Smoke 低減に及ぼす要因（酸素含有率，予混合化，噴霧 の発達とピストン壁面へのインピンジメント等）は複合効果として働き，条件によっては支配的な要因が異なっ てくると考えられるので，今後さらに検討が必要な点と思われる.

以上の結果から，1-ブタノール混合軽油に RME，またはPME を添加することにより，潤滑性を改善させるだ けでなく，着火性も改善させ，また，RME 添加の場合には排ガス中の NOx 濃度を若干増加させるものの，RME， PME の両添加もと Smoke 濃度を低減させる効果を持つ.

\section{5. 結論}

（1）1-ブタノール 40mass\%混合燃料は，RME，PME 混合割合が増加寸るほど，着火遅れは短くなり，高負荷 において最大熱発生率が低下する．また，正味熱効率は全ての供試燃料でほぼ同じであった。

（2）1-ブタノール 40mass\%混合燃料は，RME，PME 混合割合が増加するほど，高負荷で排ガス中り Smoke 濃 度は低減する (RME の NOx 濃度は若干増加)。 HC， CO 濃度は RME 混合燃料の場合， RME 混合割合の影響は ほとんどなかったが，PME 混合燃料の場合，PME 混合割合が増加するにつれて，HC，CO 濃度は低減した。

（3）B40G60 の Smoke 濃度はほぼ同じ酸素含有率の G20R80，G25P75 より低くなった．すなわち，Smoke 低減 は RME，PME 混合よりも1-ブタノール混合の方が高い.

終わりに，本研究の一部は科学研究費（基盤研究(C)，\#23560240）により実施した．また，実験には鹿児島大 学 亀田昭雄 技術専門員, 伏見和代 技術職員, 学部生 久木崎雅 君の協力を得た。ここに記して謝意を表します.

(1) Crabbe, E., et al., Biodiesel production from crude palm oil and evaluation of butanol extraction and fuel properties, Process Biochemistry, 37 (2001), 65-71.

(2) Karabektas, M., et. al., Utilization of palm oil alkyl esters as an additive in ethanol-diesel and butanol-diesel blends, Renewable Energy, 34 (2009), 1618-1624.

(3) 尾堂裕之・他 2 名, バイオディーゼル/ブタノール／軽油のディーゼル燃料性状に関する研究, 機講論, No.128-1 (2012), 347-345.

（4）木下英二, 中野裕己, 1-ブタノール軽油混合燃料のディーゼル燃焼特性，自技論, 41-5 (2010), 1101-1106.

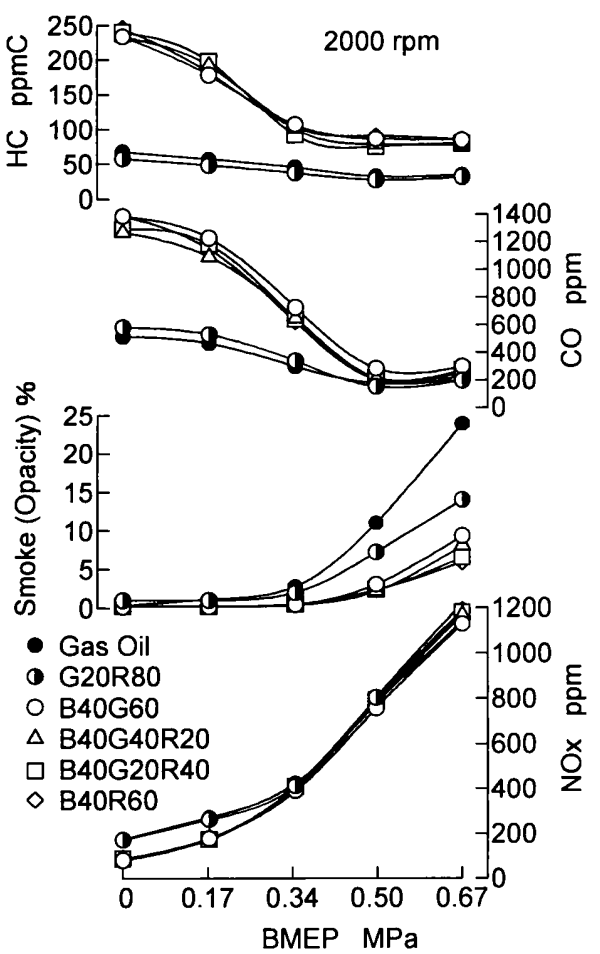

Fig.4 Exhaust emissions of RME blends

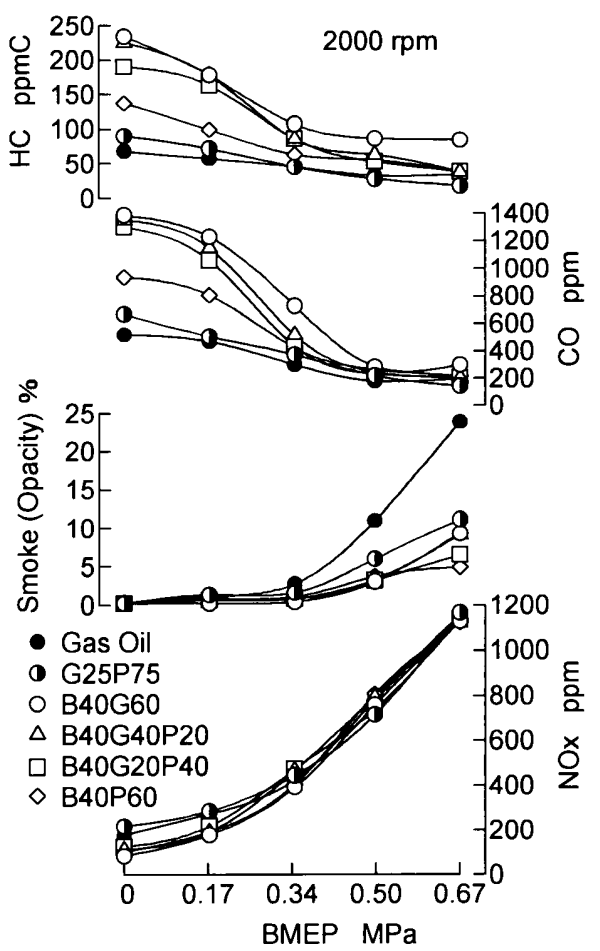

Fig.5 Exhaust emissions of PME blends 